\title{
Yield of Sweet Pepper (Capsicum annuum) Cultivars in Northwestern Puerto Rico ${ }^{1}$
}

\author{
Angel C. Serrano Pérez²
}

\begin{abstract}
Ten sweet pepper cultivars were tested to determine their yield potential in northwestern Puerto Rico. Nine plantings were made from September 1970 to July 1972 using both transplant and direct seeding methods. Puerto Rico Wonder (bell type) and Blanco del País (condiment type) outyielded similar cultivars in all cases. They are well adapted to the environmental conditions of northwestern Puerto Rico.

The best time for direct seeding appears to be January through April, while June is best for transplanting. Direct seeding is recommended because planting can be mechanized, setbacks avoided, and better yields harvested earlier.

These two cultivars were reevaluated against Yolo Wonder $Y$ and Cubanelle, using the direct seeding method. Six plantings were made from August 29,1972 , to June 6,1973 . The results confirmed previous findings.
\end{abstract}

\section{INTRODUCTION .}

Sweet pepper (Capsicum annuum), native to Tropical America $^{3}$, has been widely consumed in Puerto Rico since early colonial days. It is a favorite in salads, stuffed with ground meat as a main course, and as a condiment.

Sweet pepper production of $1969-70$ was valued at $\$ 1.5$ million at the farm level. ${ }^{4}$ During 1970-71, 46,000 cwt of fresh fruit, with an approximate value of $\$ 1$ million, ${ }^{5}$ were imported from the United States and the Dominican Republic. Imports of processed peppers are not included.

Research to determine methods of increasing production of sweet pepper was re-initiated in 1970-71. The main objective of the program was to test performance of newly available varieties, against those previously developed, using various planting schedules. A secondary objective was to compare direct seeding with transplanting from the seedbed, the traditional method in Puerto Rico.

This paper reports on the first two cycles of the program conducted at the Isabela Substation in northwestern Puerto Rico during 1970-73.

\footnotetext{
${ }^{1}$ Manuscript submitted to Editorial Board October 21, 1975.

${ }^{2}$ Assistant Agronomist, Isabela Substation, Agricultural Experiment Station, Mayagüez Campus, University of Puerto Rico, Río Piedras, P.R.

${ }^{3}$ Boswell, Victor R., Doolittle, S. P., Pultz, Leon M., Taylor, A. L., and Danielson, L. L, Pepper production, USDA, ARS, Agri. Inf. Bull. No. 276. 1964.

${ }^{4}$ Enfoques y Programa de la Estación Experimental Agricola, págs. 83-9, 1971.

${ }^{5}$ Rodríguez de Zapata, L., Hortalizas y Legumbres: Situación Actual de la Industria, Estac. Exp. Agr., Río Piedras, P.R. Inform. mimeogr., 1973.
} 


\section{MATERIALS AND METHODS}

\section{MONTHLY PLANTINGS}

Cultivars were selected according to preference of consumers in Puerto Rico and in the United States. Ten cultivars were evaluated, including eight bell types: Yolo Wonder A, California Wonder, Florida Giant, Yolo Wonder Y, California Wonder E, Early California Wonder, Yolo Wonder L, Puerto Rico Wonder, and two condiment types: Blanco del País and Cubanelle.

Nine plantings were made. The transplanting method was used in the first and second, set on September 18, and October 13, 1970, respectively. The third and fourth plantings were by direct seeding in the field on November 23, and January 26, 1971, respectively. The first four crops were replicated on a monthly schedule.

With the fifth planting, objectives were broadened to include two distinct types of experiments. In one, seedbeds were prepared and plantlets transplanted to the field. In the other, seeds were sown directly in the field. These later crops were replicated on a bimonthly schedule. The first cycle of the research program was completed with the ninth planting.

Plots were $40 \times 3 \mathrm{ft}$, and plants were set $1 \times 3$ in, with a total of 40 plants/plot, in complete randomized block designs.

Seeds for transplanting were sown in metal flats and kept under 50\% shade 4 weeks. Then seedlings were removed outside for hardening under direct sunlight. After 35 days the plants were set in the field. Direct seeding was by hand.

Tests were conducted on a Coto clay, a Tropeptic Haplorthox, clayey, mixed, isohyperthermic. The soil was plowed following the hot fallow method. ${ }^{6}$ During soil preparation, calcium carbonate was added to adjust soil $\mathrm{pH}$ to 6.5. Parathion ${ }^{7}, 15 \mathrm{lb} /$ acre, was applied for cutworm control. A side dressing of 1/2 ton/acre of 5-10-10 fertilizer was applied when plants were set in the field or at a height of about 5 in for plants directly seeded. An additional $1 / 2$ ton of fertilizer was applied after the second picking. Ammonium sulfate was also used as a side dressing in two applications, each at the rate of $250 \mathrm{lb} / \mathrm{acre}$. The first application was made when first flowers appeared; the second, after the first picking.

\footnotetext{
1" Thorne, G, and Román, J., Fallow controls nematodes on tomato production, J. Agr. Univ. P.R., 48(2): 163-4, 1964.

7 Trade names are used in this publication solely for the purpose of providing specific information. Mention of a trade name does not constitute a guarantee or warranty of equipment or materials by the Agricultural Experiment Station of the University of Puerto Rico or an endorsement over other equipment or materials not mentioned.
} 
Enide W-50 (Dyphenamid) was applied as a pre-emergent herbicide at $12 \mathrm{lb} /$ acre. Cultivation was mechanized whenever possible; otherwise, weeds were removed by hand. A monthly weeding was necessary, beginning 30 days after the application of the pre-emergent herbicide.

Diazinon AG-500 and Dithane M-45 were applied weekly to prevent insect damage as well as diseases caused or transmitted by insects and fungi. In planting 9, Lannate was used to control aphids, which apparently had developed resistance to insecticides such as Malathion, Diazinon, Thiodan, and Parathion.

Water was applied every other day, at the rate of $1 / 2$ in/acre, until seedlings were well established, usually from 2 to 3 weeks after planting. Afterward, 1-in applications were made weekly when necessary.

Harvesting began 2 months after transplanting and 3 months after direct seeding (early varieties) in each case. Afterward, peppers were harvested every 2 weeks.

Table 1 gives information for each of the nine plantings of the first cycle including time of planting and of first and last pickings. It also includes information on maximum and minimum temperatures, rainfall, and irrigation for each planting. Date of last harvest was usually 2 to 6 months from seeding. Minimum temperatures throughout the experimental cycle ranged from $19^{\circ}$ to $21^{\circ} \mathrm{C}$, and maximum temperatures ranged from $26^{\circ}$ to $29^{\circ} \mathrm{C}$. Differences between minimum and maximum temperatures fluctuated only from $7^{\circ}$ to $9^{\circ} \mathrm{C}$. Rainfall varied from $521 \mathrm{~mm}$ for the fifth transplanting (June 8, through October 10, 1971) to $932 \mathrm{~mm}$ for the fifth seeding (April 29, through October 28, 1971).

Transplanting 8 (October 16, 1971) was discarded because of crop failure due to an early virus infection. In that crop, aphids could not be controlled with standard commercial insecticides such as Diazinon, Malathion, Thiodan, or Parathion. On succeeding plantings, aphids were controlled with Lannate.

\section{BIMONTHLY PLANTINGS}

Varieties planted bimonthly included two bell type cultivars (Yolo Wonder Y and Puerto Rico Wonder) and two yellow condiment types (Blanco del País and Cubanelle).

Six plantings were made by direct seeding. The hand-sown seed was planted August 29, October 13, and December 12, 1972, and February 7, May 2, and June 6, 1973. The program called for bimonthly plantings, but adverse weather conditions necessitated adjustments to fit the six plantings within the year. There were only 15 days between the first two 
plantings, 3 months between the second and third, and 1 month between the last two. Other plantings (4 and 6) were within the scheduled time intervals. One planting had to be made in May instead of April, and another in June in order to get the six plantings within the scheduled year.

The plots were $20 \times 6 \mathrm{ft}$ in all tests. Plants were thinned to 1 in apart in rows $3 \mathrm{ft}$ apart with 40 plants/plot, in complete randomized block designs.

The tests were conducted in the same area as were the previous monthly plantings. Soil preparation, liming, fertilization, irrigation, and harvesting were done in the same way as for the first cycle.

TABLE 1.-Dates of planting and of first and last picking; climatic conditions and irrigation during first experimental cycle of pepper variety trials, 1970-72.

\begin{tabular}{|c|c|c|c|c|c|c|c|c|c|}
\hline \multirow{2}{*}{$\begin{array}{l}\text { Plant- } \\
\text { ing }\end{array}$} & \multirow[b]{2}{*}{ Planting method } & \multirow{2}{*}{$\begin{array}{l}\text { Date of } \\
\text { transplant- } \\
\text { ing or } \\
\text { seeding }\end{array}$} & \multirow{2}{*}{$\begin{array}{c}\text { Date of } \\
\text { first } \\
\text { picking }\end{array}$} & \multirow{2}{*}{$\begin{array}{c}\text { Date of } \\
\text { last } \\
\text { picking }\end{array}$} & \multicolumn{2}{|c|}{ Temperature } & \multirow{2}{*}{$\begin{array}{l}\text { Rain- } \\
\text { fall }\end{array}$} & \multirow{2}{*}{$\begin{array}{c}\text { Irri- } \\
\text { gation }\end{array}$} & \multirow{2}{*}{$\begin{array}{l}\text { Total } \\
\text { rainfall } \\
\text { and ir- } \\
\text { rigation }\end{array}$} \\
\hline & & & & & $\begin{array}{l}\text { Maxi- } \\
\text { mum }\end{array}$ & $\begin{array}{l}\text { Mini- } \\
\text { mum }\end{array}$ & & & \\
\hline No. & & & & & ${ }^{\circ} \mathrm{C}$ & ${ }^{\circ} \mathrm{C}$ & $M m$ & $M m$ & $M m$ \\
\hline 1 & Transplant & $8-8$ & 0 & 1 & 28 & 21 & 748.53 & 228.6 & 977.13 \\
\hline 2 & Tra & 10 & & & 2 & 1 & & 26 & 1162.31 \\
\hline 3 & Dire & $11-$ & & & 2 & 1 & & 39 & 1230.96 \\
\hline 4 & eeding & $1-26$ & $5-1$ & $7-2$ & 2 & 1 & 83 & 269.5 & 1208.70 \\
\hline \multirow[t]{2}{*}{$r$} & Trans & $6-8-7$ & $7-21$ & 10 & & 1 & 521 & 147.0 & 668.30 \\
\hline & Di & 4. & & & & 0 & & 127.0 & 1058.92 \\
\hline \multirow[t]{2}{*}{6} & $\mathrm{Tr}$ & $8-4-71$ & 9 & $12-1$ & 2 & 20 & 590.45 & 171.5 & 761.95 \\
\hline & Dire & $6-29$ & & $12-1$ & 2 & 20 & 829.08 & 294.0 & 1123.08 \\
\hline \multirow[t]{2}{*}{7} & Tran & $8-31$ & 71 & $12-20$ & 2 & 20 & 534.10 & 196.0 & 730.10 \\
\hline & Dire & $7-22$ & & $12-20-71$ & 29 & 20 & 634.79 & 294.0 & 928.79 \\
\hline \multirow[t]{2}{*}{9} & Transplant & $12-28-71$ & $3-6-72$ & $6-5-72$ & 28 & 19 & 602.70 & 122.5 & 725.20 \\
\hline & Direct seeding & $11-16-71$ & $2-24-72$ & $7-5-72$ & 28 & 19 & 791.10 & 254.0 & 1045.10 \\
\hline
\end{tabular}

Spraying with Lannate, Kocide-101 and Dithane M-45 followed a weekly schedule to prevent insect damage to plants and fruits and to control diseases.

Table 2 gives information for each of the six plantings, including dates of planting and of first and last pickings. Maximum and minimum temperatures, rainfall, and irrigation for each crop are recorded. Harvesting the crop extended from $2^{1 / 2}$ to 6 months. Minimum temperatures ranged from $19^{\circ}$ to $21^{\circ} \mathrm{C}$, while maximum temperatures ranged from $28^{\circ}$ to $30^{\circ} \mathrm{C}$. Differences between minimum and maximum temperatures fluctuated from $9^{\circ}$ to $10^{\circ} \mathrm{C}$. Rainfall varied from $590 \mathrm{~mm}$ for the first planting (August 29, 1972 through March 5, 1973) to 1,032 $\mathrm{mm}$ for the sixth planting (June 6 through September 15, 1973). 


\section{RESULTS AND DISCUSSION}

FIRST CYCLE

\section{Transplanting Experiments}

Table 3 shows significant differences at the 5\% level between the mean yields of both Blanco del País and Yolo Wonder $Y$ and of most other varieties in planting 1 . There were no significant differences in planting 2 among Yolo Wonder Y, Florida Giant, Puerto Rico Wonder, and Blanco del País, all of which produced between 7.2 and 8.2 tons/acre.

In planting 5, Blanco del País outyielded Yolo Wonder L and California Wonder at the 5\% level, and all other varities at the $1 \%$ level. In planting 6, Blanco del País, Yolo Wonder L, and Cubanelle outyielded, at the 1\% level, Yolo Wonder Y and Yolo Wonder A, and, at the 5\% level, California Wonder E. Blanco del País also outyielded California

TABLE 2.-Dates of planting and of first and last picking; climatic conditions and irrigation during second experimental cycle of pepper variety trials, 1972-73

\begin{tabular}{|c|c|c|c|c|c|c|c|c|}
\hline \multirow{2}{*}{$\begin{array}{l}\text { Plant- } \\
\text { ing }\end{array}$} & \multirow{2}{*}{$\begin{array}{l}\text { Date of } \\
\text { seeding }\end{array}$} & \multirow{2}{*}{$\begin{array}{l}\text { Date of } \\
\text { first } \\
\text { picking }\end{array}$} & \multirow{2}{*}{$\begin{array}{c}\text { Date of } \\
\text { last } \\
\text { picking }\end{array}$} & \multicolumn{2}{|c|}{ Temperature } & \multirow[b]{2}{*}{ Rainfall } & \multirow{2}{*}{$\begin{array}{l}\text { Irri- } \\
\text { gation }\end{array}$} & \multirow{2}{*}{$\begin{array}{l}\text { Total } \\
\text { rainfall } \\
\text { and } \\
\text { irrigation }\end{array}$} \\
\hline & & & & $\begin{array}{l}\text { Maxi- } \\
\text { mum }\end{array}$ & $\begin{array}{l}\text { Mini- } \\
\text { mum }\end{array}$ & & & \\
\hline No. & & & & ${ }^{\circ} \mathrm{C}$ & ${ }^{\circ} \mathrm{C}$ & $M m$ & $M m$ & $M m$ \\
\hline 1 & $8-29-72$ & $11-27-72$ & $3-5-73$ & 29 & 19 & 590.8 & 381.0 & 971.8 \\
\hline 2 & $9-14-72$ & $12-26-72$ & $6-27-73$ & 29 & 19 & 882.65 & 304.8 & 1187.45 \\
\hline 3 & $12-12-72$ & $3-5-73$ & $8-21-73$ & 28 & 19 & 838.2 & 279.4 & 1117.6 \\
\hline 4 & $2-7-73$ & $5-9-73$ & $9-17-73$ & 29 & 19 & 850.13 & 254,0 & 1104.13 \\
\hline 5 & $5-2-73$ & $8-8-73$ & $10-9-73$ & 30 & 21 & 853.0 & 330.2 & 1183.2 \\
\hline 6 & $6-6-73$ & $9-15-73$ & $2-25-74$ & 29 & 19 & 1032.76 & 228.6 & 1261.36 \\
\hline
\end{tabular}

Wonder at the 5\% level. Puerto Rico Wonder and Florida Giant outyielded Yolo Wonder Y at the 1\% level. Early California Wonder and California Wonder outyielded Yolo Wonder Y at the 5\% level. The differences between the mean yields of California Wonder, Cubanelle, Yolo Wonder L, and California Wonder E were significant. In planting 7, mean yields of Yolo Wonder L were significantly lower than those of Florida Giant, Yolo Wonder A, Early California Wonder, and Yolo Wonder Y. In Planting 9, Puerto Rico Wonder, Blanco del País, and Florida Giant produced significantly higher yields at the $1 \%$ level than Yolo Wonder Y, Early California Wonder, Yolo Wonder A, and Cubanelle. Furthermore, Puerto Rico Wonder outyielded California Wonder, Yolo Wonder L, and California Wonder E; Blanco del País outyielded California Wonder.

Results from all crops were pooled and statistically analyzed. Blanco del País outyielded Yolo Wonder A and Yolo Wonder L at the 5\% level. There were no other significant differences. 


\section{Direct Seeding Experiments}

Table 4 presents data on yield from the direct seeding experiments. In planting 3 , the first direct seeding experiment, Puerto Rico Wonder outyielded all other varieties at the $5 \%$ level. While Puerto Rico Wonder produced 2.25 tons/acre, all others produced less than 1 ton/acre except Yolo Wonder Y, which produced 1.10 tons/acre.

In planting 4, there were highly significant differences between mean yields of Florida Giant and those of Early California Wonder and Cubanelle. There were no other significant differences among varieties.

In planting 5, Yolo Wonder Y, Blanco del País, and Puerto Rico Wonder outyielded California Wonder at the $1 \%$ level. Yolo Wonder L

TABLE 3.-Yields per planting (metric tons per hectare) of 10 pepper varieties at Isabela Substation (transplant), first cycle, 1970-72)

\begin{tabular}{lcccccc}
\hline & \multicolumn{5}{c}{ Yields at indicated planting - } \\
\cline { 2 - 7 } \multicolumn{1}{c}{ Varieties } & $\begin{array}{c}1 \\
(8-8-70)\end{array}$ & $\begin{array}{c}2 \\
(10-13-70)\end{array}$ & $\begin{array}{c}5 \\
(6-8-71)\end{array}$ & $\begin{array}{c}6 \\
(8-4-71)\end{array}$ & $\begin{array}{c}7 \\
(8-31-71)\end{array}$ & $(12-28-71)$ \\
\hline Yolo Wonder A & $4.3 \mathrm{f}^{1}$ & $18.4 \mathrm{~cd}$ & $29.9 \mathrm{~b}$ & $14.4 \mathrm{~cd}$ & $10.7 \mathrm{a}$ & $13.5 \mathrm{~d}$ \\
California Wonder & $9.9 \mathrm{bcd}$ & $21.1 \mathrm{ab}$ & $26.7 \mathrm{~b}$ & $17.6 \mathrm{bc}$ & $11.5 \mathrm{a}$ & $15.6 \mathrm{c}$ \\
Florida Giant & $9.9 \mathrm{bcd}$ & $25.8 \mathrm{a}$ & $24.6 \mathrm{~b}$ & $20.1 \mathrm{~b}$ & $10.8 \mathrm{ab}$ & $16.3 \mathrm{~cd}$ \\
Cubanelle & $9.2 \mathrm{de}$ & $17.3 \mathrm{~cd}$ & $26.5 \mathrm{~b}$ & $22.2 \mathrm{ab}$ & $11.5 \mathrm{a}$ & $16.1 \mathrm{c}$ \\
Yolo Wonder Y & $13.0 \mathrm{a}$ & $24.0 \mathrm{a}$ & $24.9 \mathrm{~b}$ & $11.0 \mathrm{~d}$ & $9.9 \mathrm{ab}$ & $14.3 \mathrm{~d}$ \\
California Wonder E & $8.5 \mathrm{ef}$ & $21.5 \mathrm{ab}$ & $26.9 \mathrm{~b}$ & $16.0 \mathrm{~cd}$ & $6.3 \mathrm{bc}$ & $14.5 \mathrm{c}$ \\
Early California Wonder & $4.9 \mathrm{f}$ & $19.5 \mathrm{~cd}$ & $23.8 \mathrm{~b}$ & $18.5 \mathrm{bc}$ & $10.4 \mathrm{ab}$ & $14.1 \mathrm{~cd}$ \\
Blanco del País & $12.3 \mathrm{ab}$ & $21.5 \mathrm{ab}$ & $36.8 \mathrm{a}$ & $23.5 \mathrm{a}$ & $6.6 \mathrm{bc}$ & $19.2 \mathrm{a}$ \\
Yolo Wonder L & $4.9 \mathrm{ef}$ & $15.5 \mathrm{~cd}$ & $29.1 \mathrm{~b}$ & $22.8 \mathrm{ab}$ & $5.0 \mathrm{c}$ & $13.6 \mathrm{~d}$ \\
Puerto Rico Wonder & $7.6 \mathrm{ef}$ & $23.5 \mathrm{a}$ & $23.4 \mathrm{~b}$ & $21.6 \mathrm{~b}$ & $9.5 \mathrm{ab}$ & $18.7 \mathrm{a}$ \\
Average yield & 8.4 & 20.8 & 27.3 & 18.8 & 9.2 & 15.6 \\
\hline
\end{tabular}

${ }^{1}$ Mean values with one or more letters in common do not differ significantly at the $5 \%$ level.

and Yolo Wonder A also outyielded California Wonder, but at the 5\% level. Yolo Wonder Y, Blanco del País, and Puerto Rico Wonder also outyielded Cubanelle at the $5 \%$ level.

Puerto Rico Wonder, Blanco del País, and California Wonder E, in planting 6, outyielded, at the $1 \%$ level, Yolo Wonder Y and Yolo Wonder L. Cubanelle and Florida Giant also outyielded Yolo Wonder Y. All varieties, except Yolo Wonder L, outyielded Yolo Wonder Y. Puerto Rico Wonder also outyielded California Wonder E, California Wonder, and Yolo Wonder $\mathrm{A}$ at the $1 \%$ level.

In planting 7, the mean yield differences between Florida Giant and Yolo Wonder Y, Cubanelle, Early California Wonder, California Wonder E, and Puerto Rico Wonder were highly significant. Yolo Wonder L also outyielded, at the $1 \%$ level, Yolo Wonder A and Cubanelle. Florida Giant outyielded all other varities except Yolo Wonder L. The latter outyielded the remaining varieties except for Yolo Wonder A. 
In planting 9, Puerto Rico Wonder, Blanco del País, and Florida Giant outyielded the other varieties at the $1 \%$ level; and all others at the $5 \%$ level. Yolo Wonder Y was the lowest yielder.

The analysis of the combined data from all crops directly seeded reveals that Puerto Rico Wonder, Florida Giant, and Blanco del País outyielded Yolo Wonder, Cubanelle, and Early California Wonder at the $5 \%$ level.

\section{Transplanting Vs. Direct Seeding}

Transplanting is a worldwide traditional method in pepper production. However, it is expensive even when mechanical aids are used; it is time consuming and may cause setbacks in plant growth. Direct seeding

TABLE 4. - Yields per planting (metric tons per hectare) of 10 pepper varieties tested at Isabela Substation (direct seeding), first cycle, 1970-72

\begin{tabular}{|c|c|c|c|c|c|c|c|}
\hline \multirow[b]{2}{*}{ Varieties } & \multicolumn{7}{|c|}{ Yields at indicated planting- } \\
\hline & $\begin{array}{c}3 \\
(11-23-70)\end{array}$ & $\begin{array}{c}4 \\
(1-26-71)\end{array}$ & $\begin{array}{c}5 \\
(4-29-71)\end{array}$ & $\begin{array}{c}6 \\
(6-29-71)\end{array}$ & $\begin{array}{c}7 \\
(7-22-71)\end{array}$ & $\begin{array}{c}9 \\
(11-16-71)\end{array}$ & Mean \\
\hline Yolo Wonder A & $3.1 \mathrm{~b}^{1}$ & $21.9 \mathrm{a}$ & $41.0 \mathrm{a}$ & $11.1 \mathrm{bc}$ & $15.7 \mathrm{bc}$ & $22.7 \mathrm{~b}$ & 19.2 \\
\hline California Wonder & $2.6 \mathrm{bc}$ & $26.5 \mathrm{a}$ & $27.5 \mathrm{~b}$ & $10.9 \mathrm{bc}$ & $15.1 \mathrm{c}$ & & 18.0 \\
\hline Florida Giant & $2.0 \mathrm{ed}$ & $36.1 \mathrm{a}$ & $31.2 \mathrm{~b}$ & $12.2 \mathrm{ab}$ & $19.9 \mathrm{a}$ & $36.8 \mathrm{a}$ & 23.0 \\
\hline Cubanelle & $1.3 \mathrm{~cd}$ & $13.8 \mathrm{~b}$ & $34.1 \mathrm{~b}$ & $12.6 \mathrm{ab}$ & $12.2 \mathrm{c}$ & $23.8 \mathrm{~b}$ & 16.3 \\
\hline Yolo Wonder Y & $3.7 \mathrm{~b}$ & $25.5 \mathrm{a}$ & $39.3 \mathrm{a}$ & $4.0 \mathrm{~d}$ & $12.1 \mathrm{c}$ & $13.7 \mathrm{c}$ & 16.3 \\
\hline California Wonder E & $3.7 \mathrm{~b}$ & $25.8 \mathrm{~b}$ & $33.5 \mathrm{~b}$ & 13.5 & $14.3 \mathrm{c}$ & $27.4 \mathrm{~b}$ & 19.7 \\
\hline $\begin{array}{l}\text { Early California } \\
\text { Wonder }\end{array}$ & $2.8 \mathrm{bc}$ & $15.6 \mathrm{a}$ & $35.7 \mathrm{~b}$ & $10.6 \mathrm{bc}$ & $14.2 \mathrm{c}$ & $20.2 \mathrm{bc}$ & 16.6 \\
\hline Blanco del País & & 24 & $41.2 \mathrm{a}$ & 16. & & & 22.8 \\
\hline Yolo Wonder L & $2.8 \mathrm{bc}$ & $30.1 \mathrm{~b}$ & $40.9 \mathrm{a}$ & $6.0 \mathrm{~cd}$ & $18.9 \mathrm{ab}$ & $27.0 \mathrm{~b}$ & 21.0 \\
\hline Puerto Rico Wonder & $5.8 \mathrm{a}$ & $28.3 \mathrm{~b}$ & $38.7 \mathrm{a}$ & $16.6 \mathrm{a}$ & $14.6 \mathrm{c}$ & $42.3 \mathrm{a}$ & 24.4 \\
\hline Mean & 3.0 & 24.7 & 36.4 & 11.3 & 15.2 & 27.8 & \\
\hline
\end{tabular}

${ }^{1}$ Mean values with one or more letters in common do not differ significantly at the $5 \%$ level.

can be done more easily mechanically, avoids setbacks, costs less, and produces earlier and more abundant crops. Tables 2 and 3 present results from the monthly plantings. The higher yield from direct seeding may be explained by the better, more uniform stands obtained from this method. The tabulation below compares transplanting with direct seeding, irrespective of varities, for planting 5 through 9 , except for crop 8, which failed. Yields are expressed in metric tons per hectare:

Planting Number

5

6

7

9
Transplanting

25.3

17.8

9.2

15.6
Direct Seeding

36.3

12.5

15.3

27.8 
The following tabulation shows the number of pickings required to harvest plantings 5 through 9 , crop 8 excluded:

Planting Number

5

6

7

9
Transplanting

8

6

5

10
Direct Seeding

8

6

5

12

There was no significant difference in number of pickings for planting method. Crops 1 and 2 (transplanted) were harvested in seven and six pickings, respectively. Crops 3 and 4 (direct seeding) required two and six pickings respectively. Yields of crop 3 were lowest (tables 2 and 3 ).

\section{Time of Planting}

The following tabulation shows time of planting and yield (metric tons per hectare) for the first cycle of experiments:

\section{Time of Planting \\ Yield}

Transplant

August 8, 1970

8.5

October 13, 1970

20.8

June 8, 1971

27.3

August 4, 1971

18.8

August 21, 1971

9.2

December 28, 1971

15.6

January 26, 1971

April 29, 1971

June 29, 1971

July 22, 1971

15.3

November 16, 1971

30.0

June was the best month for transplanting, while August was the worst. January, April, and November were best months for direct seeding. In the direct planting of November 1970 thinning and fertilization were delayed. Plants were only about $1 \mathrm{ft} \mathrm{high} \mathrm{at} \mathrm{flowering} \mathrm{when}$ they normally reach $1^{1 / 2}$ or $2 \mathrm{ft}$. This planting was severely attacked by virus when very young and tender. It was near old pepper fields. The November 1971 planting was isolated from other pepper fields as well as from any solanaceous plants.

The April 1971 direct planting was favored by light and frequent showers. The seed for the June 1971 transplanting was sown in April 1971, at the same time as the direct seeded crop. Both had favorable weather under field conditions, resulting in heavier crops. 


\section{SECOND CYCLE}

Table 5 gives yields of four pepper varieties. There were no significant differences between the mean yields of the four varieties in the August planting. In the September planting, there were significant differences between the mean yield of Blanco del País and Puerto Rico Wonder at the 5\% level. Blanco del País and Puerto Rico Wonder outyielded Yolo Wonder Y at the 1\% level; Cubanelle outyielded Yolo Wonder Y at the $5 \%$ level, but Puerto Rico Wonder also outyielded Cubanelle at the $1 \%$ level and Blanco del País at the 5\% level.

In the December planting, Puerto Rico Wonder and Blanco del País outyielded Yolo Wonder $\mathrm{Y}$ at the 5\% level, but Yolo Wonder Y outyielded Cubanelle at the 5\% level. Puerto Rico Wonder and Blanco del País outyielded Cubanelle at the $1 \%$ level.

In the February planting, Blanco del País and Puerto Rico Wonder again outyielded Yolo Wonder Y at the 5\% level. Blanco del País and Puerto Rico Wonder outyielded Cubanelle at the 1\% and 5\% levels, respectively.

TABLE 5. - Yields per planting (metric tons per hectare) of four pepper varieties tested at Isabela Substation 1972-73, second cycle

\begin{tabular}{lccccccc}
\hline \multirow{2}{*}{ Varieties } & \multicolumn{7}{c}{ Yields at indicated planting - } \\
\cline { 2 - 7 } & $\begin{array}{l}1 \\
\text { August }\end{array}$ & $\begin{array}{c}2 \\
\text { September }\end{array}$ & $\begin{array}{c}3 \\
\text { December }\end{array}$ & $\begin{array}{c}4 \\
\text { February }\end{array}$ & $\begin{array}{c}5 \\
\text { May }\end{array}$ & $\begin{array}{c}6 \\
\text { June }\end{array}$ & \\
\hline Yolo Wonder Y & $17.4 \mathrm{a}^{\mathrm{I}}$ & $17.9 \mathrm{c}$ & $61.6 \mathrm{~b}$ & $48.7 \mathrm{~b}$ & $7.4 \mathrm{c}$ & $7.9 \mathrm{~b}$ & $26.8 \mathrm{~b}$ \\
Puerto Rico Wonder & $17.3 \mathrm{a}$ & $50.3 \mathrm{a}$ & $80.3 \mathrm{a}$ & $65.5 \mathrm{a}$ & $14.1 \mathrm{c}$ & $7.6 \mathrm{~b}$ & $36.7 \mathrm{a}$ \\
Blanco del País & $14.7 \mathrm{a}$ & $38.0 \mathrm{~b}$ & $78.9 \mathrm{a}$ & $71.1 \mathrm{a}$ & $32.5 \mathrm{a}$ & $13.5 \mathrm{a}$ & $40.3 \mathrm{a}$ \\
Cubanelle & $14.8 \mathrm{a}$ & $31.3 \mathrm{~b}$ & $41.1 \mathrm{c}$ & $47.3 \mathrm{~b}$ & $21.1 \mathrm{~b}$ & $6.0 \mathrm{~b}$ & $30.5 \mathrm{~b}$ \\
Mean & 16.1 & 34.3 & 65.5 & 58.1 & 18.8 & 8.8 & \\
\hline
\end{tabular}

${ }^{1}$ Values with one or more letters in common do not differ significantly at the $5 \%$ level.

In the May planting, Blanco del País outyielded the other three varieties at the $1 \%$ level. Cubanelle outyielded Yolo Wonder Y and Puerto Rico Wonder at the $1 \%$ level. In the June planting, Blanco del País outyielded all other varieties at the 5\% level.

The analysis of combined data of all crops revealed that Puerto Rico Wonder and Blanco del País outyielded Yolo Wonder Y at the 1\% level, while Puerto Rico Wonder outyielded Cubanelle at the 5\% level. These results confirm those of the first cycle.

Table 5 shows effect of time of planting on yields for the second cycle of experiments.

The high yields during mid-October, December, and February were again probably influenced by the well distributed rainfall, the mild temperature, and the intermediate length of day prevailing during the period. Apparently long days with heavy rainfall and high temperature do not provide favorable climatic conditions for growth of pepper plants. 
High yields from October, December, and February plantings also apparently confirm results from monthly plantings of the first cycle in similar months.

\section{OVERALL EVALUATION OF VARIETIES}

Based on the results herein reported, varieties Blanco del País, Puerto Rico Wonder, Yolo Wonder, and Cubanelle are recommended for future, more refined testing. Blanco del País and Puerto Rico Wonder are the best yielders. Blanco del País, a native variety, is very well adapted to the northwestern region and can withstand adverse conditions. Although its fruits are smaller than those of other varities, local consumers prefer it. Puerto Rico Wonder was highly resistant to virus diseases. Its fruits are not uniform but may be improved through breeding and selection. Yolo Wonder $\mathrm{Y}$ is recommended because of its good yields, high resistance to viruses, and desirable commercial characteristics, such as large, heavy, uniform fruits.

Cubanelle was not a heavy yielder, except for September, October, and November plantings. However, it has long uniform fruits and is preferred by local consumers.

Florida Giant is not recommended and will not be retained for further testing although it produced high yields, particularly when seeded directly. It is not uniform and is highly susceptible to bacterial and Fusarium wilt. During the summer months it is attacked by Cercospora and other fungi. Because of these limitations, it requires extensive and careful protection throughout the crop cycle. All other bell type varieties, except Puerto Rico Wonder and Yolo Wonder Y, are also highly susceptible to viruses and other pests and are not recommended.

\section{RESUMEN}

En el primer ciclo de un programa de evaluación de variedades de pimiento de 1970 a 1973 se evaluaron 10 variedades ( 8 del tipo campana y 2 del tipo largo), en siembras mensuales en diferentes épocas. En unas se sembró la semilla directamente en el campo y en otras plantitas de semilleros.

Los meses de noviembre a abril son los mejores para la siembra directa de pimiento en la zona noroeste. Junio es el mejor mes para la siembra por trasplante.

En el segundo ciclo se evaluaron cuatro variedades de pimiento seleccionadas por sus altos rendimientos, resistencia a enfermedades y preferencias del consumidor.

En este ciclo de siembras se lograron los rendimientos más elevados durante los meses de octubre, diciembre y febrero. Las variedades Blanco del País y Puerto Rico Wonder superaron en rendimientos a la Yolo Wonder Y y a la Cubanelle.

Las siembras del segundo ciclo (cada 2 meses) confirmaron los resultados del primer ciclo.

En el análisis combinado de todas las siembras, las variedades Puerto Rico Wonder y Blanco del País, la primera de las cuales fue desarrollada por la Estación hace muchos años, superaron a las otras ocho variedades en rendimiento. Se confirmó que estas dos variedades se adaptan bien a la región noroeste de Puerto Rico y que pueden producir buenas cosechas aun bajo condiciones adversas para otras variedades.

En términos generales, se obtuvieron mejores rendimientos cuando la semilla se sembró directamente en el cainpo que cuando se trasplantó. En la siembra directa las plantas se desarrollaron más rápidamente, lográndose así una cosecha inicial más temprana. 